\title{
THE SOMATOSTATIN RECEPTOR-ADENYLATE CYCLASE SYSTEM IN RAT PANCREATIC ACINAR MEMBRANES AFTER TEMPORARY PANCREATICOBILIARY DUCT LIGATION
}

\author{
E. Rodríguez-Martín ${ }^{1}$, I. Álvaro-Alonso ${ }^{1}$, G. Bodega ${ }^{2}$ and E. Arilla ${ }^{1 *}$. \\ ${ }^{1}$ Unidad de Neuroendocrinología Molecular, Departamento de Bioquimica y Biología \\ Molecular, Facultad de Medicina and ${ }^{2}$ Departamento de Biología Celular y Genética. \\ Universidad de Alcalá, E-28871, Alcalá de Henares, Madrid, Spain.
}

(Received in final form September 8, 1997)

\begin{abstract}
Summary
The mechanism whereby somatostatin (SS) produces beneficial effects in established pancreatitis induced by pancreaticobiliary duct ligation (PBDL) is still not clear. The aim of the work was to evaluate the possibility of a direct action of SS on pancreatic acinar cells from rats with acute pancreatitis. For this purpose, we studied the SS-receptor-adenylate cyclase system in pancreatic acinar membranes from both, control rats and rats with experimentally induced acute pancreatitis. On the other hand, it has been reported that cholecystokinin (CCK) diminishes the number of SS receptors in pancreatic acinar cells. Proglumide, a CCK receptor antagonist reduces the severity of acute pancreatitis in the rat. Therefore, we have also examined the effect of proglumide on the somatostatinergic system in controls and rats with acute pancreatitis. Fourteen hours after PBDL, the SS receptors, the capacity of the SS analogue SMS 201-995 to inhibit forskolin-stimulated adenylate cyclase activity and PTX-catalyzed [ $\left.{ }^{32} \mathrm{P}\right]$ ADP-ribosylation of the $\alpha_{1}$ subunits of $\mathrm{Gi}$ proteins could not be detected in pancreatic acinar membranes. One month after reopening the closed pancreaticobiliary duct (PBD), the pancreas showed regeneration of acinar cells, and the above-mentioned parameters were significantly lower than in the control group. Two months after reopening the closed PBD, all these parameters had returned to control values. The administration of proglumide $(20 \mathrm{mg} / \mathrm{kg}$ i.p. $)$, a cholecystokinin receptor antagonist, accelerated pancreatic regeneration and approached all these parameters to control values one month after reopening the closed PBD. The present study suggests that the beneficial effects of SS on established pancreatitis induced by PBDL may not be due to a direct action of the peptide on pancreatic acinar cells at least at 14 hours after PBDL. In addition, these findings suggest that in established pancreatitis the effect of proglumide on the SS receptor-adenylate cyclase system could be due to its action on pancreatic regeneration.
\end{abstract}

Key Words: pancreatitis, somatostatin receptors, exocrine pancreas, cAMP, Gi proteins

*Author to whom correspondence should be addressed. Fax: +34-1-885 4585 . 
A variety of receptors on pancreatic acinar and ductal cells regulate both pancreatic exocrine secretion and intracellular processes. These receptors are potential sites of action for therapeutic agents in the treatment of pancreatitis (1). Some cholecystokinin (CCK) receptor antagonists, which may reduce the levels of metabolic "stress" in acinar cells, have been shown to mitigate the severity of acute pancreatitis in a number of models $(2,3,4)$. Somatostatin (SS) and its analogs also mitigate the severity of acute pancreatitis. The use of SS in acute pancreatitis was first suggested in 1975 (5). Previous studies investigating the effects of SS on experimentally induced pancreatitis have provided conflicting results $(6,7,8)$. SS as well as its long-acting analogue have been reported to improve survival rate and pancreatic histopathology in rats with pancreaticobiliary duct ligation (PBDL)(7).

The mechanism whereby SS produces beneficial effects in established pancreatitis induced by PBDL is still not clear. Recent studies have shown the existence of SS receptors on pancreatic acinar cells $(9,10)$, indicating that SS acts directly on acinar cells. These receptors are coupled to the adenylate cyclase (AC) enzyme system via a guanine nucleotide inhibitory protein $\mathrm{Gi}(11)$. The aim of the present study was to evaluate the possibility of a direct action of SS on pancreatic acinar cells from rats with acute pancreatitis. Therefore, we studied the SS receptor-AC system in pancreatic acinar membranes from controls and rats with acute pancreatitis. On the other hand, since PBDL-induced acute pancreatitis in rats is associated with a rise in plasma CCK levels (12) and proglumide, a CCK-receptor antagonist reduces the severity of acute pancreatitis in the rat (3), we have also studied the effect of proglumide on the somatostatinergic system in control rats and rats with acute pancreatitis. Thus, the present study examined the binding of a radioiodinated stable SS-14 analogue, SMS 204-090 or [Tyr $\left.{ }^{3}\right]$ SMS, to its specific receptors, the ability of the SS analogue SMS 201-995 to inhibit forskolin (FK)-stimulated AC activity and pertussis toxin (PTX)-catalyzed $\left[{ }^{32} \mathrm{P}\right]$ ADP-ribosylation of the $\alpha$ subunits of Gi proteins in rat pancreatic acinar membranes fourteen hours after PBD ligation (PBDL) and one or two months after reopening the closed PBD. SS in the pancreas is localized in the (so-called) D -cells $(13,14)$ in the islets of Langerhans (15). Because there is a close interaction between the islets and the exocrine tissue, which appears in part to be mediated by an insulinoacinar portal system $(16,17)$, SS-like immunoreactivity (SSLI) in the pancreas of these animals was also studied.

\section{Materials and Methods}

\section{Chemicals}

The stable SS analogue SMS 201-995 and its tyrosine analogue Tyr ${ }^{3}-S M S$ or SMS 204-090 were kindly donated by Sandoz Ltd., (Basel, Switzerland). Collagenase (from Clostridium histoliticum) was obtained from Serva Fine Chemicals (Tebu, France). Proglumide, bacitracin, phenylmethylsulphonylfluoride (PMSF), guanosine triphosphate (GTP), 3-isobutyl-1methylxanthine (IBMX), pertussis toxin (PTX) and bovine serum albumin (BSA) were purchased from Sigma (St. Louis, MO, USA). Carrier-free $\left.\mathrm{Na}^{125} \mathrm{I}\right]$ (IMS $300,100 \mathrm{mCi} / \mathrm{ml}$ ) and the rabbit antibody used in the radioimmunoassay technique were purchased from the Radiochemical Center (Amersham, U.K.). This antiserum was raised in rabbits against SS-14 conjugated to BSA and is specific for SS, but since SS-14 constitutes the C-terminal portion of both SS-25 and SS-28, the antiserum does not distinguish between thesc three forms. In the rat pancreas, SS-14 is the predominant molecular species, constituting $95 \%$ of total SS, whereas SS-28 seems to comprise less than $5 \%$ of the immunoreactivity (18). All other agents were of the highest purity commercially available. 


\section{Experimental animals}

The animals experiments performed in the present study were conducted under the guidelines of the Animal Care Committee of Alcala University, Medical School and the experimental protocols have been approved. Male Wistar rats weighing 200-250 g were anesthetized with $40 \mathrm{mg} / \mathrm{kg}$ of ketamine hydrochloride administered intramuscularly. The abdomen was opened by a midline incision and the proximal duodenum exposed. Acute pancreatitis was induced by ligation of the PBD with a silk string at its point of entry into the duodenum, thereby allowing reflux of bile to the pancreas (19). Subsequently, the abdominal wall was closed in two layers using a non-absorbable suture. Fourteen hours after ligation, twenty rats were sacrificed and another forty rats were subjected to a second laparotomy to reopen the closed PBD by removing the silk. These rats were sacrificed one and two months after reopening the closed PBD. Control rats were submitted to a sham operation. Proglumide, a CCK receptor antagonist, was administered intraperitoneally $(20 \mathrm{mg} / \mathrm{kg})$ to thirty rats one hour before and six hours after PBD occlusion. The drug dose was selected according to the effective dose reported in previous studies (20). The animals were decapitated at the times indicated and the pancreas was removed and trimmed free of fat, connective tissue and lymph nodes.

\section{Histological study}

For light microscopy, fragments of pancreas were quickly removed and fixed two days at room temperature in $10 \%$ formaldehyde buffered to $\mathrm{pH} 7.0$. The fragments were subsequently embedded in paraffin, sectioned in $9 \mu \mathrm{m}$ slices and stained by the Masson trichrome method.

\section{Preparation of rat pancreatic acinar membranes}

Dispersed pancreatic acini were obtained from male Wistar rats after enzymatic degradation of the organ with 0.2 units of collagenase $/ \mathrm{ml}$ in an oxygenated Krebs-Ringer medium as described by Amsterdam et al. (21). After thorough washing by sedimentation, acini were transferred to $0.3 \mathrm{M}$ sucrose. In $0.3 \mathrm{M}$ sucrose, the acini were homogenized at $4^{\circ} \mathrm{C}$ by use of a Potter homogenizer following the Meldolesi et al. method (22). After sedimentation at 1,500 x $\mathrm{g}$ for $12 \mathrm{~min}$, the homogenized membranes were resuspended in $1.56 \mathrm{M}$ sucrose. This suspension was overlaid with $0.3 \mathrm{M}$ sucrose, and centrifuged at $105,000 \mathrm{x} \mathrm{g}$ for $150 \mathrm{~min}$. The plasma membrane-enriched fraction collected from the interphase was diluted with distilled water and centrifuged at $15,000 \times \mathrm{g}$ for $30 \mathrm{~min}$. The supernatant was discarded and the pellet was resuspended in $50 \mathrm{mM}$ Tris/ $\mathrm{HCl} \mathrm{pH} 7.4,0.01 \mathrm{mg} / \mathrm{ml}$ bacitracin, $0.2 \mathrm{mM} \mathrm{CaCl}$ and stored at $70^{\circ} \mathrm{C}$. An aliquot was taken for protein determination by the method of Lowry et al. (23).

\section{Binding of $\left[^{125} I-T^{2} r^{3}\right] S M S$}

Binding of $\left[{ }^{125}\left[-\mathrm{Tyr}^{3}\right]\right.$ SMS was assayed on pancreatic acinar membranes from Wistar rats by a modified method (24). The stable SS-14 analogue, SMS 204-090 or [Tyr ${ }^{3}$ ]SMS, which shares the biological properties of SMS 201-995 and has proven valuable in the characterization of SS-14 binding to receptors in rat pancreatic acinar (10) and brain (25) membranes, was radioiodinated by the chloramine-T-method and purified by HPLC according to Antoniotti et al. (26). Its specific radioactivity was found to be $900 \mathrm{Ci} / \mathrm{mmol}$.

Binding of $\left.{ }^{125} \mathrm{I}-\mathrm{Tyr}^{3}\right]$ SMS to pancreatic acinar membranes was carried out in a total volume of $250 \mu \mathrm{l}$ in $50 \mathrm{mM}$ Tris- $\mathrm{HCl}$ buffer (pH 7.4) containing $0.5 \mathrm{mM} \mathrm{MgCl}, 3 \mathrm{mM} \mathrm{NaCl}$, $0.2 \mathrm{mM} \mathrm{CaCl} 2,0.2 \%$ (wt/vol) $\mathrm{BSA}, 0.5 \mathrm{mg} / \mathrm{ml}$ bacitracin and $0.3 \mathrm{mg} / \mathrm{ml}$ soybean trypsin inhibitor (binding buffer). Plasma membranes (36 $\mu \mathrm{g}$ protein $/ \mathrm{ml}$ ) were incubated for $90 \mathrm{~min}$ at 
$20^{\circ} \mathrm{C}$ with $35 \mathrm{pM}\left[{ }^{125} \mathrm{I}-\mathrm{Tyr}^{3}\right] \mathrm{SMS}$ in the absence or presence of $0.001-10 \mathrm{nM}$ unlabelled SMS 201995. Bound and free ligand were separated by centrifugation at $11,000 \times \mathrm{g}$ for $4 \mathrm{~min}$ at $4^{\circ} \mathrm{C}$ in a microcentrifuge. Radioactivity in the pellet was measured with a gamma scintillation counter. Non-specific binding was estimated as membrane-associated radioactivity in the presence of $1 \mu \mathrm{M}$ SMS and specific binding was calculated as the difference between total and non-specific membrane-associated radioactivity.

\section{Adenylate cyclase assay}

AC activity was measured as previously reported (27) with minor modifications. Briefly, rat pancreatic acinar membranes $(0.12 \mathrm{mg}$ protein $/ \mathrm{ml})$ were incubated with $1.5 \mathrm{mM}$ ATP, $5 \mathrm{mM}$ $\mathrm{MgSO}_{4}, 1 \mu \mathrm{M}$ GTP and an ATP-regenerating system $(7.5 \mathrm{mg} / \mathrm{ml}$ creatine phosphate and $1 \mathrm{mg} / \mathrm{ml}$ creatine kinase), $1 \mathrm{mM}$ IBMX, $0.1 \mathrm{mM}$ PMSF, $1 \mathrm{mg} / \mathrm{ml}$ bacitracin, $1 \mathrm{mM}$ EDTA, and tested substances $\left(10^{-9} \mathrm{M}\right.$ SMS $201-995$ or $\left.10^{-5} \mathrm{M} \mathrm{FK}\right)$ in $0.1 \mathrm{ml}$ of $0.025 \mathrm{M}$ triethanolamine/ $\mathrm{HCl}$ buffer (pH 7.4). After a 30 min incubation at $30^{\circ} \mathrm{C}$, the reaction was stopped by heating the mixture for $3 \mathrm{~min}$. After refrigeration, $0.2 \mathrm{ml}$ of an alumina slurry $(0.75 \mathrm{~g} / \mathrm{ml}$ in triethanolamine/ $\mathrm{HCl}$ buffer, pH 7.4) was added and the suspension centrifuged. The supernatant was taken for assay of cyclic AMP by the method of Gilman (28).

\section{Pertussis toxin-catalyzed ADP ribosylation}

The pertussis-toxin (PTX)-catalyzed ADP- ribosylation was carried out as previously reported (29). After PTX activation, membranes $(0.8 \mathrm{mg}$ protein $/ \mathrm{ml})$ were incubated with PTX $(16 \mu \mathrm{g} / \mathrm{ml})$ in $100 \mathrm{mM}$ Tris-HCl buffer ( $\mathrm{pH} 8.0)$, containing $10 \mathrm{mM}$ thymidine, $1 \mathrm{mM} \mathrm{ATP}, 100$ $\mu \mathrm{M}$ GTP, $2.5 \mathrm{mM} \mathrm{MgCl}, 1 \mathrm{mM}$ EDTA, $2 \mu \mathrm{M}\left[{ }^{32} \mathrm{P}\right] \mathrm{NAD}^{+}(30 \mathrm{Ci} / \mathrm{mmol})$ and an ATPregenerating system. After $30 \mathrm{~min}$ at $30^{\circ} \mathrm{C}$, the reaction was stopped by addition of $1 \mathrm{ml}$ of icecold $100 \mathrm{mM}$ Tris-HCl buffer ( $\mathrm{pH} \mathrm{8.0)}$ ), proteins were sedimented by centrifugation for $10 \mathrm{~min}$ at $30,000 \times \mathrm{g}$ and solubilized with $0.1 \mathrm{ml} 60 \mathrm{mM}$ Tris-HCl buffer $(\mathrm{pH} 6.8)$ containing $10 \%$ glycerol, $0.001 \%$ bromophenol blue and 3\% SDS (SDS-sample buffer). After heating for $30 \mathrm{~min}$ at $60^{\circ} \mathrm{C}$, the suspension was centrifuged for $10 \mathrm{~min}$ at $100,000 \mathrm{x} \mathrm{g}$ and aliquots of the supernatant were submitted to SDS-PAGE using the procedure of Laemmli (30) as previously described (31). The gels were run, fixed, dried and exposed to Dupont films (cronex 4) for $1-7$ days at $-80^{\circ} \mathrm{C}$ using an intensifying screen.

\section{Tissue extraction and SS radioimmunoassay}

[Tyr $\left.{ }^{11}\right] \mathrm{SS}$ was radioiodinated by chloramine- $\mathrm{T}$ iodination according to the method of Greenwood (32). Separation of iodinated SS from unincorporated iodine was carried out on a Sephadex G-25 (fine) column equilibrated and eluted with $0.1 \mathrm{M}$ acetic acid in BSA $(0.1 \% \mathrm{w} / \mathrm{v})$. Its specific activity was found to be $600 \mathrm{Ci} / \mathrm{mmol}$.

For SSLI measurement, the pancreas were rapidly homogenized in $1 \mathrm{ml} 2 \mathrm{M}$ acetic acid using a Brinkman polytron (setting $5,30 \mathrm{~s}$ ). The extracts were boiled for $5 \mathrm{~min}$, cooled in an icechilled water-bath, and aliquots $(100 \mu \mathrm{l})$ were removed for protein determination (23). The homogenates were subsequently centrifuged at $15,000 \times \mathrm{g}$ for $15 \mathrm{~min}$ at $4^{\circ} \mathrm{C}$ and the supernatant was neutralized with $2 \mathrm{M} \mathrm{NaOH}$. The extracts were stored at $-70^{\circ} \mathrm{C}$ until assay. The SS concentration was determined in tissue extracts by a modified radioimmunoassay method (14), with a sensitivity limit of $10 \mathrm{pg} / \mathrm{ml}$. Incubation tubes prepared in duplicate contained $100 \mu \mathrm{l}$ samples of tissue extracts or standard solutions of $0-500$ pg of cyclic SS-14 diluted in phosphate buffer $(0.05 \mathrm{M}, \mathrm{pH} 7.2$ containing $0.3 \%$ BSA, $0.01 \mathrm{M}$ EDTA), $200 \mu \mathrm{l}$ of appropriately diluted anti-SS-serum and $100 \mu \mathrm{l}$ of freshly prepared [ $\left.{ }^{125} \mathrm{I}-\mathrm{Tyr}^{11}\right] \mathrm{SS}$ diluted in buffer to give $6,000 \mathrm{cpm}$ 
(equivalent to $5-10 \mathrm{pg}$ ), in a final volume of $0.8 \mathrm{ml}$. All reagents as well as the assay tubes were kept chilled on ice before their incubation at $4^{\circ} \mathrm{C} 48 \mathrm{~h}$. Bound hormone was separated from free hormone by the addition of $1 \mathrm{ml}$ of dextran-coated charcoal (dextran T-70, 0.2\% w/v, Pharmacia, Uppsala, Sweden; charcoal: Norit A, 2\% w/v, Serva, Feinbiochemica, Heidelberg, Germany). Serial dilution curves for the samples were parallel to the standard curve. The intra and interassay variation coefficients were 6.0 and $8.8 \%$ respectively.

\section{Data analysis}

The LIGAND computer program (33) was used to analyze the binding data. The use of this program made it possible to select the models of receptors which best fit a given set of binding data. The same program was also used to present data in the form of Scatchard plots (34) and to compute the values for receptor affinity (Kd) and density (Bmax) that best fit the sets of binding data for each rat. Statistical comparisons of all the data were analyzed by ANOVA and the Newman-Keuls t-test. Means among groups were considered significantly different when the $p$ value was less than 0.05 . Each individual experiment was performed in duplicate.

\section{Results}

Fourteen hours after PBD ligation, several features of acute pancreatitis were present; edema, inflammatory cell infiltration, necrosis and hemorrhage were observed around intralobular and interlobular ducts and, less frequently, in a perilobular location (Fig. 1, 1B). One month after reopening the closed PBD, the pancreas showed regeneration of acinar cells (Fig. 1, 1C). Two months after reopening the closed PBD, the pancreatic structure was fully restored (data not shown).

Specific binding of $\left.{ }^{125} \mathrm{I}-\mathrm{Tyr}^{3}\right]$ SMS to pancreatic acinar membranes changed linearly with protein concentration and was time-dependent in all experimental groups. An apparent equilibrium was observed between 60 and $120 \mathrm{~min}$ at $20^{\circ} \mathrm{C}$ (data not shown). All subsequent binding experiments were therefore conducted at $20^{\circ} \mathrm{C}$ for $90 \mathrm{~min}$. Ligand degradation in the incubation medium was determined to rule out the possibility of different $\left[{ }^{125} \mathrm{I}-\mathrm{Tyr}^{3}\right] \mathrm{SMS}$ degrading activities in each of the preparations which might have affected the interpretation of the results. Pancreatic acinar membranes from each experimental group showed a similar peptide degradation capacity and the values varied by no more than $10 \%$ among experimental groups.

Increasing concentrations of unlabelled SMS 201-995 competitively inhibited the specific binding of [125I-Tyr $\left.{ }^{3}\right] S M S$ to rat pancreatic acinar membranes in both control and treated rats (Fig. 2 , left panel). Scatchard plots obtained from the saturation curves provided a straight line, indicating a single population of high-affinity saturable binding sites (Fig. 2, right panel). Table 1 shows the corresponding equilibrium parameters for the SS receptors. Fourteen hours after occlusion of the PBD, no SS receptors were detected and one month after reopening the closed PBD, the number of SS receptors and their affinity was still significantly lower than in the control group. Two months after reopening the closed PBD, the number of SS receptors and the affinity constant had returned to control values. 


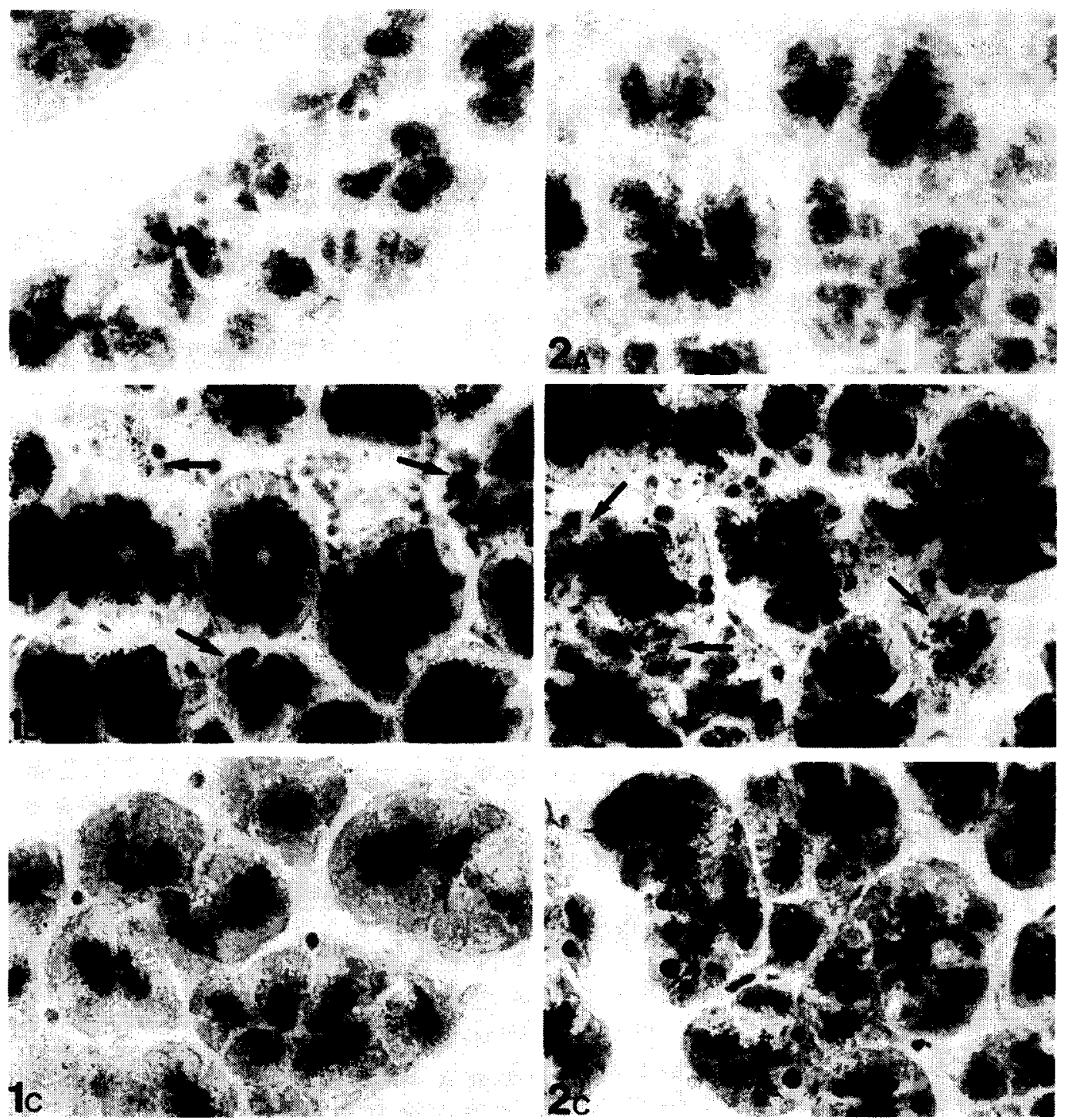

FIG. 1

Time course of histological changes after pancreaticobiliary duct ligation (PBDL) and reopening the closed pancreaticobiliary duct (PBD) $x$ 475. Control rats killed fourteen hours after sham-operation show no changes (1A). Fourteen hours after PBDL, there is a mild interstitial edema, inflammatory cell infiltration, necrosis and hemorrhage. Arrows indicate destroyed pancreatic acinar tissue (1B). One month after reopening the closed PBD, the previous histologic findings were normalized (1C). The administration of proglumide $(20 \mathrm{mg} / \mathrm{kg}$ i.p.) had no observable effect in control rats (2A) and rats sacrificed fourteen hours after PBDL (2B). However, its administration did accelerate pancreatic regeneration at one month after reopening the closed PBD (2C). 
TABLE I

Pancreatic somatostatin-like immunoreactive (SSLI) content and equilibrium parameters for [ ${ }^{125} \mathrm{I}-$ $\mathrm{Tyr}^{3}$ ]SMS binding to rat pancreatic acinar membranes at fourteen hours atter pancreaticobiliary duct ligation (PBDL), one and two months after reopening the closed pancreaticobiliary duct (PBD) and to pancreatic acinar membranes from rats treated with proglumide $(20 \mathrm{mg} / \mathrm{kg}$ i.p.) one hour before and six hours after PBD occlusion.

\begin{tabular}{|c|c|c|c|}
\hline \multirow{2}{*}{ Groups } & \multicolumn{2}{|c|}{ SS receptors } & \multirow[t]{2}{*}{ SSLI } \\
\hline & $B \max$ & $\mathrm{Kd}$ & \\
\hline \multicolumn{4}{|l|}{14 hours } \\
\hline Control & $4646 \pm 80$ & $0.28 \pm 0.02$ & $3.22 \pm 0.30$ \\
\hline Proglumide & $4678 \pm 117$ & $0.33 \pm 0.02$ & $3.17 \pm 0.32$ \\
\hline PBDL & ND & ND & $8.06 \pm 0.84 * * *$ \\
\hline \multicolumn{4}{|l|}{ PBDL + } \\
\hline Proglumide & ND & ND & $3.08 \pm 0.09$ \\
\hline \multicolumn{4}{|l|}{1 month } \\
\hline Control & $4718 \pm 95$ & $0.29 \pm 0.03$ & $3.96 \pm 0.46$ \\
\hline Proglumide & $4665 \pm 147$ & $0.33 \pm 0.02$ & $3.84 \pm 0.33$ \\
\hline Reopening & $2354 \pm 246^{* * * *}$ & $0.40 \pm 0.01 *$ & $9.69 \pm 0.05^{* * *}$ \\
\hline Reopening + & & & \\
\hline Proglumide & $4086 \pm 84 * *$ & $0.46 \pm 0.01 *$ & $4.80 \pm 0.08$ \\
\hline \multicolumn{4}{|l|}{2 months } \\
\hline Control & $4663 \pm 66$ & $0.34 \pm 0.01$ & $4.21 \pm 0.52$ \\
\hline Proglumide & $4585 \pm 154$ & $0.36 \pm 0.01$ & $4.00 \pm 0.46$ \\
\hline Reopening & $4547 \pm 194$ & $0.35 \pm 0.03$ & $3.19 \pm 0.33$ \\
\hline \multicolumn{4}{|l|}{ Reopening + } \\
\hline Proglumide & $4368 \pm 268$ & $0.40 \pm 0.02$ & $5.55 \pm 0.23$ \\
\hline
\end{tabular}

Binding parameters were calculated from Scatchard plots by linear regression. Units for SSLI are $\mathrm{ng}$ of SS per $\mathrm{mg}$ of protein, units for $\mathrm{Kd}$ are $\mathrm{nM}$ and units for Bmax are femtomoles of SMS bound per $\mathrm{mg}$ of protein. Each value is the mean \pm S.E.M. of six rats per group performed in duplicate. Statistical comparison versus control: ${ }^{*} p<0.05,{ }^{* *} p<0.01,{ }^{* * *} p<0.001$. ND: not detectable.

The functional coupling of SS receptors to the AC system was studied in pancreatic acinar membranes from control and treated rats. Fourteen hours after PBDL both basal and FKstimulated AC activity were not detectable in PBD-ligated rats and were lower one month after reopening of the closed PBD as compared to controls (Tables 2 and 3). The fold FK stimulation over basal AC activity, however, was similar in all experimental groups, in sharp contrast with the SS effects. Since FK is believed to act directly upon the catalytic subunit of AC, these data suggest that the activity of $\mathrm{AC}$ is independent per se of pancreatic regeneration. The capacity of SMS 201-995 to inhibit basal and FK-stimulated AC activity in controls and at fourteen hours after PBDL and at one and two months after reopening of the PBD is shown in Tables 2 and 3. It is to be noted that SMS 201-995 did not modify basal AC activity although it did inhibit FKstimulated AC activity. The inhibitory effect of SMS 201-995 on FK-stimulated AC activity was not detectable at fourteen hours after PBDL and markedly decreased in pancreatic acinar membranes at one month after reopening of the PBD as compared to control animals and returned 
to control values two months after the reopening.

The study of PTX-catalyzed ADP-ribosylation showed a decrease in a $41 \mathrm{kD}$ PTX substrate, presumably the $\alpha_{1}$ subunil of $\mathrm{Gi}$, in ral pancreatic acinal membranes one month after reopening the closed PBD when compared with the control group (Fig. 3). Two months after reopening the closed $\mathrm{PBD}$, this parameter returned to control values (data not shown). Fourteen hours after PBD ligation, PTX-catalyzed ADP-ribosylation was not detectable (Fig.3).

Pancreatic SSLI content was increased fourteen hours after PBDL and one month after reopening the closed PBD. Two months after reopening the closed PBD, pancreatic SSLI content had returned to control values (Table 1).

\section{TABLE II}

Effect of SMS 201-995 $\left(10^{-9} \mathrm{M}\right)$ and forskolin (FK) $\left(10^{5} \mathrm{M}\right)$ on adenylate cyclase (AC) activity (pmol cAMP/min $/ \mathrm{mg}$ protein) in pancreatic acinar membranes from control rats, rats with pancreaticobiliary duct ligation (PBDL), rats treated with proglumide $(20 \mathrm{mg} / \mathrm{kg}$ i.p.) one hour before and six hours after PBDL (PBDL +PG) and proglumide-treated rats (PG). All the groups were studied at fourteen hours after PBDL.

\begin{tabular}{|c|c|c|c|c|}
\hline Groups & Control & PG & PBDL & $\begin{array}{l}\text { PBDL } \\
+ \text { PG }\end{array}$ \\
\hline \multicolumn{5}{|l|}{14 hours } \\
\hline Basal activity & $17.8 \pm 1.4$ & $18.2 \pm 2.0$ & ND & ND \\
\hline$+10^{-9}$ M SMS & $15.2 \pm 0.9$ & $15.6 \pm 2.0$ & ND & ND \\
\hline $\begin{array}{l}\% \text { SMS inhibition of } \\
\text { basal activity }\end{array}$ & $14.6 \pm 1.2$ & $14.3 \pm 1.8$ & ND & ND \\
\hline $\begin{array}{l}+10^{-5} \mathrm{M} \text { FK } \\
\text { Fold FK stimulation }\end{array}$ & $36.9 \pm 0.7$ & $36.5 \pm 1.4$ & ND & ND \\
\hline $\begin{array}{l}\text { over basal } \\
10^{5} \mathrm{M} \mathrm{FK}+\end{array}$ & $2.1 \pm 0.7$ & $2.0 \pm 0.6$ & ND & ND \\
\hline $\begin{array}{l}10^{-9} \mathrm{M} \text { SMS } \\
\% \text { SMS inhibition of }\end{array}$ & $27.7 \pm 1.1$ & $26.1 \pm 2.9$ & ND & ND \\
\hline FK stimulation & $24.9 \pm 1.4$ & $28.5 \pm 3.2$ & ND & ND \\
\hline
\end{tabular}

Experiments were performed as described in Methods. Values represent the mean \pm S.E.M. of six rats per group performed in duplicate. ND : not detectable.

Proglumide administration $(20 \mathrm{mg} / \mathrm{kg}$ i.p.) one hour before and six hours after occluding the PBD had no observable effect on any of the parameters studied in rats sacrificed fourteen hours after PBDL. However, its administration accelerated pancreatic regeneration one month after reopening the closed PBD (Fig. 1, 2C) and the pancreatic SSLI content, the number of [ ${ }^{125} \mathrm{I}-$ Tyr ${ }^{3}$ ]SMS-binding receptors and the ability of the SS analogue SMS 201-995 to inhibit FKstimulated AC activity in rat pancreatic acinar membranes (Fig. 2, Tables 1,2 and 3) approached control values, although remaining significantly lower than in controls. Two months after reopening the closed PBD, proglumide administration had no observable effect on the parameters studied (Tables 1 and 3). Proglumide had no effect on the SS-receptor-effector system. 


\section{TABLE III}

Effect of SMS 201-995 $\left(10^{9} \mathrm{M}\right)$ and forskolin (FK) $\left(10^{-5} \mathrm{M}\right)$ on adenylate cyclase (AC) activity ( $\mathrm{pmol} \mathrm{cAMP} / \mathrm{min} / \mathrm{mg}$ protein) in pancreatic acinar membranes from control rats $(n=6)$, rats after reopening the closed pancreaticobiliary duct $(\mathrm{PBD})$ one and two months after occlusion $(n=6)$, rats treated with proglumide (PG) $(20 \mathrm{mg} / \mathrm{kg}$ i.p.) one hour before and six hours after PBD occlusion and studied one and two months after reopening the closed PBD $(n=6)$, and proglumide-treated rats $(n=6)$.

\begin{tabular}{|c|c|c|c|c|}
\hline Groups & Control & PG & Reopening & $\begin{array}{l}\text { Reopening } \\
+ \text { PG }\end{array}$ \\
\hline \multicolumn{5}{|l|}{1 month } \\
\hline Basal activity & $18.7 \pm 1.5$ & $19.1 \pm 1.1$ & $10.3 \pm 1.0^{* *}$ & $6.1 \pm 0.5^{* * *}$ \\
\hline $\begin{array}{l}+10^{-9} \mathrm{M} \text { SMS } \\
\text { \% SMS inhibition of }\end{array}$ & $16.0 \pm 1.1$ & $16.3 \pm 1.2$ & $9.0 \pm 0.5^{* * *}$ & $5.7 \pm 0.5^{* * *}$ \\
\hline basal activity & $14.4 \pm 0.9$ & $14.7 \pm 1.0$ & $12.6 \pm 0.8$ & $6.6 \pm 0.4^{* * *}$ \\
\hline$+10^{-5}$ M FK & $39.3 \pm 1.8$ & $40.0 \pm 1.4$ & $23.7 \pm 2.7^{* *}$ & $15.0 \pm 2.1^{* * *}$ \\
\hline Fold FK stimulation & & & & \\
\hline $\begin{array}{l}\text { over basal } \\
10^{-5} \mathrm{M} \mathrm{FK}+\end{array}$ & $2.1 \pm 0.7$ & $2.1 \pm 0.6$ & $2.3 \pm 0.6$ & $2.5 \pm 0.8$ \\
\hline $\begin{array}{l}10^{-9} \text { M SMS } \\
\% \text { SMS inhibition of }\end{array}$ & $29.4 \pm 1.7$ & $29.1 \pm 1.6$ & $20.2 \pm 1.7^{* *}$ & $13.4 \pm 1.9^{* * *}$ \\
\hline FK stimulation & $25.2 \pm 1.4$ & $27.3 \pm 2.1$ & $14.8 \pm 1.5^{* * *}$ & $10.7 \pm 0.9^{* * *}$ \\
\hline \multicolumn{5}{|l|}{2 months } \\
\hline Basal activity & $17.9 \pm 0.7$ & $18.2 \pm 1.2$ & $18.1 \pm 0.2$ & $18.2 \pm 1.2$ \\
\hline $\begin{array}{l}+10^{-9} \mathrm{M} \text { SMS } \\
\text { SMS inhibition of }\end{array}$ & $15.3 \pm 0.9$ & $15.5 \pm 1.1$ & $15.4 \pm 0.2$ & $15.5 \pm 1.2$ \\
\hline basal activity & $14.5 \pm 0.6$ & $14.8 \pm 1.0$ & $14.9 \pm 0.2$ & $14.8 \pm 1.0$ \\
\hline $\begin{array}{l}+10^{-3} \mathrm{M} \text { FK } \\
\text { Fold FK stimulation }\end{array}$ & $38.2 \pm 1.3$ & $37.8 \pm 3.1$ & $36.2 \pm 2.3$ & $31.5 \pm 3.0$ \\
\hline $\begin{array}{l}\text { over basal } \\
10^{-5} \mathrm{M} \mathrm{FK}+\end{array}$ & $2.1 \pm 0.7$ & $2.1 \pm 0.7$ & $2.0 \pm 0.6$ & $2.1 \pm 0.6$ \\
\hline $\begin{array}{l}10^{-9} \mathrm{M} \text { SMS } \\
\% \text { SMS inhibition of }\end{array}$ & $28.0 \pm 1.3$ & $28.3 \pm 1.9$ & $26.4 \pm 1.7$ & $28.4 \pm 2.3$ \\
\hline FK stimulation & $26.7 \pm 1.1$ & $25.1 \pm 1.7$ & $27.1 \pm 1.6$ & $24.3 \pm 1.9$ \\
\hline
\end{tabular}

Experiments were performed as described in Methods. Values represent the mean \pm S.E.M. of six rats per group performed in duplicate. Statistical comparison versus control: ${ }^{* *} p<0.01$, $* * * p<0.001$.

\section{Discussion}

Damaging pancreatic tissue by ligating the pancreaticobiliary duct (PBD) at its point of entry into the duodenum leads to histological changes consistent with acute pancreatitis (35) and reopening the obstructed PBD permits regeneration of the acinar cells from duct cells (35). Thus, reopening the obstructed PBD is a model used to study pancreatic regeneration (35). Fourteen hours after PBDL, histological changes consistent with acute pancreatitis were observed, in agreement with other authors $(35,7)$. These changes disappeared one month after reopening the closed PBD. Thus, the present study provides evidence that the chain of events leading to 
irreversible pancreatitis is not initiated during the first fourteen hours of PBDL. This conclusion agrees with studies of Oshio et al.(36) and Kueppers et al. (37). In addition, these findings indicate that regeneration was possibly almost completed within one month after removing the obstruction and reestablishing the flow. In addition, in other experimental models, spontaneous regeneration was still incomplete after 23 days (2).

A striking feature of the present investigation is the marked increase in pancreatic SSLI content fourteen hours after PBDL and one month after removing the obstruction and reestablishing the flow. To our knowledge, there are no studies on pancreatic SSLI content in acute pancreatitis and during pancreatic regeneration. However, Larsen et al. (38) have shown that plasma SS concentrations were persistently elevated in patients with chronic pancreatitis (2). With respect to a possible mechanism for the increased pancreatic SSLI content, previous studies in rats have demonstrated that CCK stimulates pancreatic SS release in vitro (39) and in vivo (40) and that chronic administration of the CCK analogue, caerulein, results in a marked increase in pancreatic SSLI content (41). It is possible, thercfore, that the change in pancreatic SSLI concentration observed in this study is the result of the increased plasma CCK concentrations described in obstruction-induced acute pancreatitis (12).

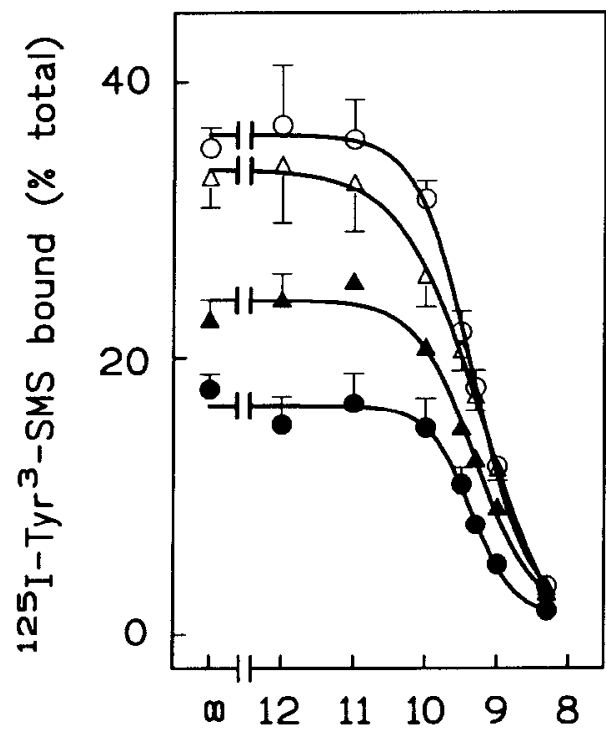

[SMS 201-995], $-\log M$

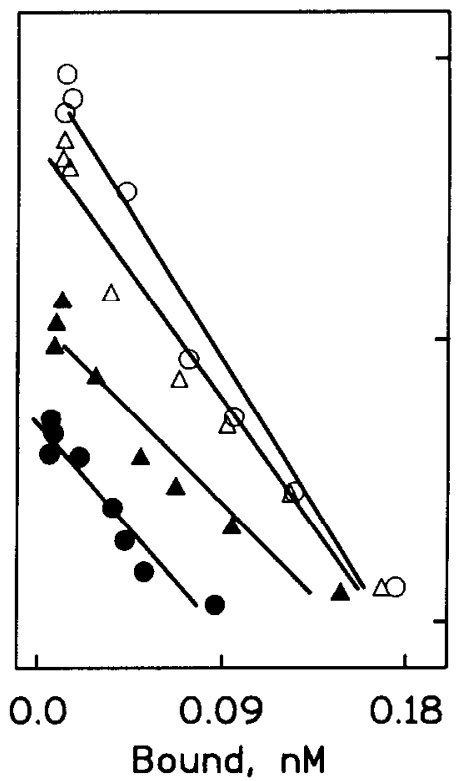

0.6

FIG. 2

Left panel: Competitive inhibition of specific $\left[{ }^{125} \mathrm{I}-\mathrm{Tyr} \mathrm{r}^{3}\right] \mathrm{SMS}$ binding to rat pancreatic acinar membranes by unlabelled SMS 201-995. Points correspond to control rats $(O)$, rats after reopening the closed pancreaticobiliary duct (PBD) one month after occlusion ( () , rats treated with proglumide one hour before and six hours after the occlusion of PBD and studied one month after reopening the closed PBD ( $\Delta$ ) and proglumide-treated rats $(\Delta)$. Each point is the mean of six rats per group performed in duplicate. Results express the value of a pool of control groups since maximal binding capacity and dissociation constant values were not affected in the control groups. Right panel: Scatchard analysis of the same data. The kinetic constants calculated by Scatchard analysis are given in Table 1 . 
Coinciding with features of acute pancreatitis such as pancreatic edema, inflammation and necrosis at fourteen hours after PBDL, the SS receptors, the capacity of the SS analogue SMS 201-995 to inhibit FK-stimulated AC activity and PTX-catalyzed $\left[{ }^{32} \mathrm{P}\right]$ ADP-ribosylation of the $\alpha_{1}$ subunits of $G_{i}$ proteins could not be detected in pancreatic acinar membranes.

Despite histological improvement at one month after reopening the PBDL, the number of SS receptors in the exocrine pancreas is still decreased. The reason why the SS receptors are less abundant in the regenerating pancreas than in quiescent adult pancreatic acinar cells and the mechanism of this change are unknown. However, several alternative explanations must be considered which include the modulation of apparent receptor number by hormones or other factors or an intracellular process that results in the loss of SS receptors.
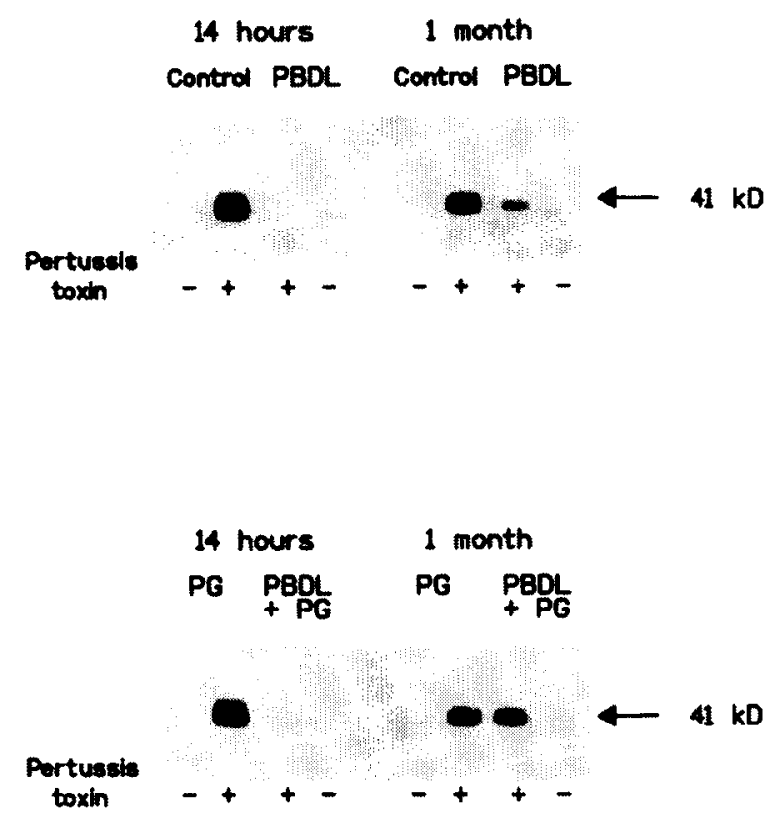

FIG. 3

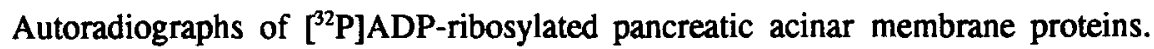
Pancreatic acinar membranes $(0.8 \mathrm{mg}$ protein $/ \mathrm{ml})$ from control rats, rats with pancreaticobiliary duct ligation (PBDL) and sacrificed at fourteen hours after PBDL or one month after reopening the closed pancreaticobiliary duct (PBD), and from proglumide-treated rats with or without PBDL and studied fourteen hours after PBDL or one month after reopening the closed PBD, were incubated for 30 min at $30^{\circ} \mathrm{C}$ in the presence of $2 \mu \mathrm{M}\left[{ }^{32} \mathrm{P}^{2} \mathrm{NAD}^{+}(30 \mathrm{Ci} / \mathrm{mmol})\right.$, with $(+)$ or without $(-)$ pertussis toxin $(16 \mu \mathrm{g} / \mathrm{ml})$. These experiments are representative of three others. For details, see Materials and Methods section.

Although the mechanisms responsible for these changes in SS binding are not clear, it is well established that high SS levels lead to decreased SS binding (9). The increase of pancreatic SSLI content one month after releasing the PBDL was found to be associated with a reduction of the number of SS receptors in pancreatic acinar cell membranes. These results suggest that an increase in endogenous SSLI content leads to desensitization or down-regulation of SS receptors 
in the exocrine pancreas. In this regard, SS receptors on rat pancreatic acinar cells are regulated by SS in vivo, as evidenced by the decreased binding in streptozotocin-induced diabetic rats, characterized by hypersomatostatinemia (9). SS-14 receptor down-regulation in vitro has also been reported in AtT-20 mouse pituitary tumor cells (42). In addition, SS binding in the exocrine pancreas is also inhibited by $\mathrm{Ca}^{2+}$-mobilizing pancreatic secretagogues such as CCK (43) and bombesin $(44)$, which are increased during pancreatic regeneration $(12,45)$. However, this effect may be due to a combination of all these factors and other as yet unknown ones.

Another possible explanation for the decrease in the number of SS receptors may be that the regenerating pancreatic acinar cells were still immature by day 30 after reopening the PBD. This hypothesis is supported by the fact that the number of SS receptors in very young rats is lower than in mature rats. Thus, the maturation of the SS receptor-AC system may take place in this context.

Other conditions of cell regeneration such as regenerating hepatocytes isolated from hepatectomized livers also show a limited response to SS-14, which may be explained by a decrease in the binding of SS-14 to membrane-specific receptors (46).

Although at least five SS receptor subtypes have been cloned (47), the rat pancreas appears to express only receptor subtype 2 (SSTR2) (48). Therefore, it is possible that the decrease in the SS receptor number during pancreatic regeneration could result, at least in part, from downregulation of the SSTR2 subtype.

The data reported here show that pancreatic acinar membrane SS receptors are coupled in an inhibitory fashion to $\mathrm{AC}$, which is in agreement with previous reports (11). One month after reopening the closed PBD, basal and FK-stimulated AC activity were lower after reopening the closed PBD as compared to controls and the ability of SMS 201-995 to inhibit AC was diminished in acinar membranes from regenerating pancreas as compared with controls. However, there did not appear to be any defect in the catalytic subunit of AC itself since similar activity levels were noted in membranes from both control and regenerating pancreas when this enzyme was stimulated directly by the diterpene FK. These results are in agreement with studies on hepatic regeneration (49). The attenuation of the inhibitory activity of SMS on AC activity observed in the present study in pancreatic acinar membranes from rats one month after reopening the closed PBD is most likely related to the observed loss of SS receptors and to alterations in the Gi proteins.

The present observation of a decrease in the extent of PTX-catalyzed ADP-ribosylation in regenerating pancreatic acinar cell membranes one month after reopening the closed PBD suggests an impairment in the inhibitory interaction between the $\alpha_{\mathrm{i}}$ protein and the AC enzyme, which could explain the attenuation of the inhibitory effect of SMS 201-995 on FK-stimulated AC activity in these membranes. Endogenous inactivation of the Gi protein has been reported in several cell types during regeneration and cell growth (50). Inactivation of Gi proteins could result from endogenous ADP-ribosylation (50) or from phosphorylation, e.g. hy protein kinase C (51). Indeed, in a number of cell types, cell proliferation or regeneration is associated with increased protein kinase $\mathrm{C}$ activation (52).

The fact that SS-receptor-AC system could not be detected in pancreatic acinar membranes fourteen hours after PBDL does not support the possibility that the beneficial effects of SS on pancreatitis-induced by PBDL may not be due to a direct action of the peptide on pancreatic acinar cell during that period. Therefore, the suggested beneficial influence of SS on PBDLinduced acute pancreatitis it could be ascribed to others mechanisms. These may include its 
inhibitory effect on duodenal CCK release (4) and bile secretion (53) as well as its marked vascular effect in the splanchnic area (54).

In this regard, obstruction-induced acute pancreatitis in rats is associated with a marked increase in circulating CCK levels (12). It has been suggested that excesive stimulation of the exocrine pancreas due to a marked elevation in circulating CCK concentration is a factor involved in the pathogenesis of PBD obstruction-induced acute pancreatitis. On the other hand, it has been reported that CCK diminishes the number of SS receptors in pancreatic acinar cells (43). Taken together, it is possible that CCK is involved in the pathogenesis of acute pancreatitis observed in the present study fourteen hours after PBDL. CCK could cause this effect by directly disrupting acinar cell and by decreasing the SS mechanism of action. This may represent a mechanism for pancreatitis.

The blockage of CCK receptors with proglumide did not modify the SS receptor-AC system in control rats and accelerated pancreatic regeneration one month after reopening the closed PBD. In addition, all parameters examined in the present study were nearly normalized. These facts suggest that the given effect of proglumide on the SS-receptor-AC system is due to its action on pancreatic regeneration. The present study agrees with previous studies which indicate that specific $\mathrm{CCK}$ receptor antagonists have been beneficially used to protect and/or reduce pancreatic damage during the induction and progression of acute pancreatitis $(2,3)$ and that CCK may play role in the pathogenesis of obstruction-induced acute pancreatitis $(55,56)$.

\section{Acknowledgements}

The authors thank Ms. Carol F. Warren and Jerry Keller from the Alcalá University Institution of Education Sciences and Lilian Puebla from the Department of Biochemistry of Alcalá University for their linguistic assistance, as well as Ms. María Baez for her excellent assistance with library research and Mr. Luis Monge for assistance in the preparation of the illustrations. The authors are also grateful to Sandoz Ltd. (Basel, Switzerland) for generous donation of SMS 201-995 and its analogue Tyr ${ }^{3}$-SMS. This study was supported by a Grant from the Dirección General de Investigación Científica y Técnica (PM95-0041) and from the University of Alcalá $(001 / 96)$ of Spain.

\section{References}

1. J.H. GRENDELL, Yale J. Biol. Med 65 431-440 (1992).

2. G. JURKOWSKA, G. GRONDIN and J. MORISSET, Pancreas 7 295-304 (1992).

3. C. NIEDERAU, L.D. FERRELL and J.H. GRENDELL, Gastroenterology 88 1192-1204 (1985).

4. Y. TORIUMI, I. SAMUEL, D.P. WILCOCKSON, C.M. TURKELSON, T.E. SOLOMON and R.J. JOEHL, J. Lab. Clin. Med. 122 450-454 (1993).

5. G. BODEN, M.C. SIVITZ and O.E. OWEN, Science 190163 (1975).

6. V. SCHWEDES, P.H. ALTHOFF, I. KLEMPA, U. LEUSCHNER, L. MOTHES, S. RAPTIS, J. WDOWINSKI and K.H. USADEL, Horm. Metab. Res. 11 655-661 (1979).

7. J.N. BAXTER, S.A. JENKINS, D.W. DAY, N.B. ROBERTS, D.C. COWELL and C.R. MACKIE, Br. J. Surg. 72 382-385 (1985).

8. P.G. LANKISH, H. KOOP, K. WINCKLER, U.R. FOLSCH and W. CREUTZFELDT, Gut 18 713-716 (1977).

9. C.B. SRIKANT and Y.C. PATEL, J. Biol. Chem. 261 7690-7696 (1986).

10. S. KNUHTSEN, J.P. ESTEVE, B. BERNADET, N. VAYSSE and C. SUSINI, Biochem. J. 254 641-647 (1988). 
11. C.T. SAKAMOTO, T. MATOZAKI, M. NAGAO and S. BABA, Am. J. Physiol. (Gastroint Liver Physiol 16) 253 G308-G314 (1987).

12. K.M. MURAYAMA, I. SAMUEL, Y. TORIUMI, T.E. SOLOMON, C.M. TURKELSON and R.J. JOEHL, J. Surg. Res. 54 126-131 (1993).

13. M. RÜNZI, M.K. MÜLLER and H. GOEBELL, Regul. Pept. 47 65-72 (1993).

14. Y.C. PATEL and S. REICHLIN, Endocrinology 102 523-531 (1978).

15. A. ARIMURA, H. SATO, A.DUPONT, N. NISHI and A.V. SCHALLY, Science 189 1007-1009 (1975).

16. J.J. HOLST, Pancreas 2 613-619 (1987).

17. A. NAKAGAWA, J.I. STAGNER and E. SAMOLS, Gastroenterology 105 868-875 (1993).

18. Y,C. PATEL, T. WHEATLEY and C. NING, Endocrinology 109 1943-1949 (1981).

19. L. BOQUIST and C. EDSTROM, Virchows Arch. Abt. A Path. Anat. 349 69-79 (1970).

20. A. DEMBINSKI, Z. WARZECHA, S.J. KONTUREK SJ, RZ. CAI and A.V. SCHALLY, J. Physiol. Pharmacol. 42 195-209 (1991).

21. A. AMSTERDAM, T.E. SOLOMON and J.D. JAMIESON, Methods Cell Biol. 20 361378 (1978).

22. J. MELDOLESI, J.D. JAMIESON and G.E. PALADE, J. Cell Biol. 49 109-129 (1971).

23. O.H. LOWRY, N.J. ROSEBROUGH, A.L. FARR and R.J. RANDALL, J. Biol. Chem. 193 265-275 (1951).

24. B. COLÁS, C. CAMbillau, L. BUSCAIL, M. ZEGGARI, J.P. ESTEVE, V. LAUTRE, F. THOMAS, N. VAYSSE and C. SUSINI, Eur. J. Biochem. 207 1017-1024 (1992).

25. J.C. REUBI, Life Sci. 36 1829-1836 (1985).

26. H. ANTONIOTTI, P. FAGOT-REVURAT, J.P. ESTEVE, D. FOURMY, L. PRADAYROL and A. RIBET, J. Chromatogr. 296 181-188 (1984).

27. M.D. HOUSLAY, J.C. METCALFE, G.P. WARREN, T.R. HESKETH and G.A. SMITH, Biochim. Biophys. Acta. 436 489-494 (1976).

28. A.G. GILMAN, Proc. Natl. Acad. Sci. USA. 67 305-312 (1970).

29. G.M. BOKOCH, T. KATADA, J.K. NORTHUP, E.L. HEWLETT and A.G. GILMAN, J. Biol. Chem. 258 2072-2075 (1983).

30. U.K. LAEMMLI, Nature 227 680-685 (1970).

31. M. LABURTHE, B. BREANT and C. ROUYER-FESSARD, Eur. J. Biochem. 139 181187 (1984).

32. F.C. GREENWOOD, W.M. HUNTER and J.S. GLOVER, Biochem. J. $\underline{89}$ 114-123 (1963).

33. P.J. MUNSON and D. RODBARD, Anal. Biochem. 1207 220-239 (1980).

34. G. SCATCHARD, Ann. N.Y. Acad. Sci. 51 669-671 (1949).

35. G.T. HULTQUIST, V. KARLSSON and A.C. HALLNER, Exp. Pathol. 17 44-52 (1979).

36. G. OHSHIO, A. SALUJA, M.L. STEER, Gastroenterology 100 196-202 (1991).

37. P.M. KUEPPERS, D.H. RUSSELL and F.G. MOODY, Pancreas $\underline{8} 632-637$ (1993).

38. S. LARSEN, J. HILSTED, B. TRONIER and H. WORNING, Acta Endocrinol. 118357 364 (1988).

39. E. IPP, R.E. DOBBS, V. HARRIS, A. ARIMURA, W. VALE and R.H. UNGER, J, Clin. Invest. 60 1216-1219 (1977).

40. D. ROUILLER D, V. SCHUSDZIARRA, V. HARRIS and R.H. UNGER, Endocrinology 107 524-529 (1980).

41. T. YAMADA, J. BRUNSTEDT and T. SOLOMON, Am. J. Physiol. 244 G541-G545 (1983).

42. S. HEISLER and C.B. SRIKANT, Endocrinology 117 217-225 (1985). 
43. C. SAKAMOTO, I.D. GOLDFINE and J.A. WILLIAMS, J. Biol. Chem. 259 9623-9627 (1984).

44. C.T. SAKAMOTO, T. MATOZAKI, M. NAGAO, H. NISHISAKI and S. BABA, Pancreas 3 18-24 (1988).

45. D. PAREKH, G. GÓMEZ, C.M. Jr. TOWNSED and J.C. THOMPSON, Gastroenterology 96 A383 (1989).

46. M. HASHIMOTO, P.C. KOTHARY and S.E. RAPER, Regul. Pept. 44 49-59 (1993).

47. D. HOYER, H. LÜBBERT and C. BRUNS, Naunyn Schmied Arch Pharmacol. 350 441453 (1994).

48. J.F. BRUNO, Y. XU, J. SONG and M. BERELOWITZ, Endocrinology 133 2561-2567 (1993).

49. L.G. GUIJARRO, A. COUVINEAU, M.S. RODRÍGUEZ-PENA, G. JUARRANZ, N. RODRÍGUEZ-HENCHE and E. ARILLA, Biochem. J. 285 515-520 (1992).

50. M. UI, F. OKAJIMA and H. ITOH, Adv. Cyclic. Nucl. Res. 19 195-205 (1985).

51. T. KATADA, A.G. GILMAN, Y. WATANABE, S. BAUER and K.H. JAKOBS, Eur. J. Biochem. 151 431-437 (1985).

52. G. KUNOS, E.J.N. ISHAC, Biochem. Pharmac. 36 1185-1191 (1987).

53. W.C. MEYERS. J.B. HANKS and R.S. JONES, Surgery 86 301-306 (1979).

54. L. THULIN and H. SAMNERGAD, Acta Chir. Scand. S482 73-77 (1978).

55. K.M. MURAYAMA, J.B. DREW, D.L. NAHRWOLD and R.J. JOEHL, Pancreas 5 439-444 (1990).

56. K.M. MURAYAMA, J.B. DREW, H. YOKOO and R.J. JOEHL, Pancreas $\underline{6}$ 175-181 (1991). 